\title{
Perbandingan Kemampuan Komunikasi Matematis Siswa antara yang Mendapatkan Model Pembelajaran Problem BASEd LEARNing DENGAN PENDEKatan REAListic MATHEMATICS EDUCATION DAN OPEN-ENDED
}

\author{
Comparing Mathematical Communication SKills of STUDENTS BETWEen \\ Problem Based Learning Model With Realistic Mathematics EduCATion AND \\ OPEN-ENDED APPROACH
}

\author{
Ulfah Syifa Alamiah $^{1}$ dan Ekasatya Aldila Afriansyah ${ }^{2}$ \\ 1 Program Studi Pendidikan Matematika, STKIP Garut \\ Garut, Jawa Barat, Indonesia \\ ulfahsyifaalamiah@gmail.com \\ ${ }^{2}$ Program Studi Pendidikan Matematika, STKIP Garut \\ Garut, Jawa Barat, Indonesia \\ e_satya@yahoo.com
}

\begin{abstract}
Abstrak
Penelitian ini dilatar belakangi oleh rendahnya kemampuan komunikasi matematis siswa yang berdampak pada rendahnya kemampuan dalam menyelesaikan soal matematika yang menuntut kemampuan komunikasi matematis siswa. Penelitian ini bertujuan untuk mengetahui perbandingan kemampuan komunikasi matematis siswa antara yang mendapatkan model Pembelajaran Problem Based Learning dengan pendekatan Realistic Mathematics Education dan open-ended. Adapun metode penelitian yang digunakan dalam penelitian ini adalah metode quasi eksperimen yang terdiri dari dua kelas, yaitu kelas eksperimen 1 yang mendapat model pembelajaran PBL dengan pendekatan RME dan kelas eksperimen 2 yang mendapat model pembelajaran PBL dengan pendekatan Open-Ended. Penelitian dilaksanakan di SMP Negeri 1 Cikajang dengan sampel penelitiannya adalah kelas VII A sebagai kelas eksperimen 1 dan VII B sebagai kelas eksperimen 2. Materi yang dijadikan bahan penelitian yaitu tentang sistem persamaan dan pertidaksamaan linear satu variabel (SPLSV). Instrumen penelitian ini berupa tes dengan bentuk uraian yang diberikan pada saat pretest dan posttest serta diberikan tes skala sikap siswa. Dari hasil penelitian dapat disimpulkan kemampuan komunikasi matematis antara siswa yang mendapatkan model pembelajaran Problem Based Learning menggunakan pendekatan Realistic Mathematic Education lebih baik dari pada pendekatan Open-Ended.

Kata Kunci: Kemampuan Komunikasi Matematis Siswa, Model Pembelajaran Problem Based Learning, Pendekatan Realistic Mathematics Education, Pendekatan Open-Ended.
\end{abstract}

\begin{abstract}
This research is based on the low ability of students \& apos mathematical communication which has an impact on the low ability to solve the mathematical problems that demand the students\&apos; mathematical communication ability. This study aims to determine the comparison of students\&apos; mathematical communication skills between Learning Problem Based Learning Model\&nbsp; with Realistic Mathematics Education and open-ended approach. The benefit of this research in general is to provide an overview of PBL learning model with RME and open-ended approach to students \& apos mathematical communication ability. The research method used in this research is a quasi experimental method consisting of two classes, namely
\end{abstract}


experimental class 1 which received PBL learning model with RME approach and experiment class 2 which got PBL learning model with Open-Ended approach. The research was conducted in SMP Negeri 1 Cikajang with the research sample is class VII $A$ as experimental class 1 and VII $B$ as experiment class 2. The material used as research material is about system of equation and linear inequality one variable (SPLSV). The instrument of this research is a test with the form of description given at the time of pretest and posttest and given the students attitude scale test. From the results obtained pretest Ho accepted so it can be concluded that there is no significant difference in students\&apos; mathematical communication between experimental class 1 and experiment class 2. From the result posttest obtained $\mathrm{Ha}$ accepted, so it can be concluded mathematical communication skills between students who get the model of learning Problem Based Learning Using the Realistic Mathematic Education approach is better than the OpenEnded approach. While the scale of student attitudes processed with Likert scale and it can be concluded that students interpret both the PBL learning model with the approach of RME and open-ended.

Keyword: Student Mathematical Communication Skill, Problem Based Learning Model, Realistic Mathematics Education Approach, Open-Ended Approach.

\section{Pendahuluan}

Matematika adalah salah satu komponen dari serangkaian mata pelajaran yang mempunyai peranan penting dalam pendidikan (Sundayana, 2015).

Dalam pembelajaran matematika ada beberapa kemampuan matematis yang harus dimiliki oleh siswa. Salah satunya ialah kemampuan komunikasi matematis yang merupakan salah satu kemampuan yang dituntut dalam kurikulum yang berlaku di Indonesia. Menurut Baroody (Husna dkk, 2013) Kemampuan ini sangat penting dan diperlukan oleh siswa baik dalam pelajaran matematika, pelajaran lain, ataupun untuk bekal mereka di kehidupan kelak.

Salah satu penyebab siswa tidak menyenangi matematika kemungkinan model pembelajaran yang diberikan oleh guru tidak sesuai atau kurang cocok dengan siswanya. Agar siswa bisa termotivasi, menyenangi pelajaran matematika dan mempunyai sikap positif terhadap matematika, maka diperlukan upaya untuk menciptakan suatu pembelajaran yang menyenangkan siswa dalam belajar, seperti yang diungkapkan Russefendi (1991) bahwa guru yang menguasai materi harus mampu mengelola strategi pembelajaran, menerapkan metode/teknik mengajar yang tepat. Salah satu model pembelajaran yang diharapkan dapat meningkatkan kemampuan komunikasi matematis dan keaktifan siswa yaitu dengan menggunakan model pembelajaran Problem Based Learning, pembelajaran dimulai dengan menyajikan masalah nyata kepada siswa untuk menstimulus siswa dalam berpikir. Hal ini bisa meningkatkan antusiasme dan ketertarikan siswa terhadap materi yang dipelajarinya karena dikaitkan dengan kehidupan nyata. Selanjutnya, guru mengorganisasikan siswa untuk belajar.

Selain model PBL, di dalam pembelajaran juga disisipkan suatu pendekatan ilmiah atau saintifik yang 
diartikan sebagai titik tolak atau sudut pandang kita terhadap proses pembelajaran yang sifatnya masih sangat umum, didalamnya mewadahi, menginspirasi, menguatkan dan melatari metode pembelajaran, dilihat dari pendekatannya, pembelajaran terdapat dua jenis pendekatan pertama berpusat pada siswa dan yang kedua berpusat pada guru (Sudrajat, 2008) untuk itu penulis lebih memilih untuk menggunakan pendekatan yang berpusat pada siswa, yang bertujuan agar siswa secara langsung aktif dalam pembelajaran yaitu dengan pendekatan Realistic Mathematics Education dan Open-Ended.

Wijaya (2012) menjelaskan bahwa RME merupakan suatu pendekatan dalam pembelajaran matemtika di Belanda. Kata "realistic" sering disalah artikan sebagai "real-world", yaitu dunia nyata, penjelasan lebih lanjut bahwa pembelajaran matematika realistik ini berangkat dari kehidupan anak, yang dapat dengan mudah dipahami oleh anak, nyata, dan terjangkau oleh imajinasinya, dan dapat dibayangkan sehingga mudah baginya untuk mencari kemungkinan penyelesaiannya dengan menggunakan kemampuan matematis yang telah dimiliki.

Wijaya ( 2012) menjelaskan bahwa Open-Ended merupakan pendekatan yang bertujuan untuk mengembangkan aktivitas kreatif dan kemampuan berpikir matematis secara simultan. Dari sisi lain, siswa juga tidak hanya diharapkan dapat menemukan penyelesaian, tetapi diminta untuk mengemukakan langkah-langkah untuk mencapai penyelesaian itu. OpenEnded juga memberikan kesempatan kepada siswa untuk memperoleh pengetahuan atau pengalaman menemukan, mengenali, dan memecahkan masalah dengan beberapa cara. Tetapi pada dasarnya siswa lebih malas ketika kita hadapkan dengan beberapa persoalan yang menantang/tingkat tinggi apalagi dengan konsep yang memang harus membutuhkan waktu yang lama agar siswa mampu memahami maksud dari permasalahan matematika tersebut, juga manakala siswa tidak memiliki minat atau tidak mempunyai kepercayaan bahwa masalah yang dipelajari sulit untuk dipecahkan, maka mereka akan merasa enggan untuk mencobanya, tetapi mungkin saja ketika siswa memulai memahami konsep matematika dengan tidak dibatasi dengan suatu konsep dan diperkenalkan dengan berbagai cara penyelesaian mungkin saja siswa lebih menyukainya karena siswa bebas memilih cara penyelesaian mana yang menurut siswa mudah dipahami seperti pada pendekatan Open-Ended, maka dari itu penulis tertarik untuk melakukan penelitian dengan judul "Perbandingan Kemampuan Komunikasi Matematis Siswa Antara Yang Mendapatkan Model Problem Based Learning dengan Pendekatan Realistic Mathematics Education dan Open-Ended".

Rumusan masalah pada penelitian ini terdiri dari lima, yaitu: 1) Apakah kemampuan komunikasi matematis siswa 
yang mendapatkan model pembelajaran Problem Based Learning menggunakan pendekatan Open-Ended lebih baik dari siswa yang menggunakan pendekatan Realistic Mathematics Education?; 2) Bagaimana kualitas peningkatan kemampuan komunikasi matematis siwa yang mendapatkan model pembelajaran Problem Based Learning dengan pendekatan Realistic Mathematics Education?; 3) Bagaimana kualitas peningkatan kemampuan komunikasi matematis siswa yang mendapatkan model pembelajaran Problem Based Learning dengan pendekatan OpenEnded?; 4) Bagaimana sikap siswa terhadap model pembelajaran Problem Based Learning dengan pendekatan Realistic Mathematics Education?; dan 5) Bagaimana sikap siswa terhadap model pembelajaran Problem Based Learning dengan pendekatan Open-Ended?

Secara umum, komunikasi dapat diartikan sebagai proses menyampaikan pesan dari seseorang kepada orang lain baik secara langsung (lisan) ataupun tidak langsung (melalui media). Kemampuan komunikasi matematis ialah kemampuan menyampaikan gagasan/ide matematis, baik secara lisan maupun tulisan serta kemampuan memahami dan menerima gagasan/ide matematis orang lain secara cermat, analitis, kritis, dan evaluatif untuk mempertajam pemahaman (Lestari dan Yudhanegara, 2015).

Sumarmo (Lestari dan Yudhanegara, 2015) menyatakan bahwa kemampuan komunikasi matematis meliputi kemampuan siswa:

1. Menghubungkan benda nyata, gambar, dan diagram ke dalam idea matematika.

2. Menjelaskan idea, situasi dan relasi matematik secara lisan atau tulisan dengan benda nyata, gambar, grafik dan aljabar.

3. Menyatakan peristiwa sehari-hari dalam bahasa atau simbol matematika.

PBL (Lestari dan Yudhanegara, 2015) merupakan model pembelajaran yang dikembangkan pertama kali oleh Prof. Howard Barrows sekitar tahun 1970-an dalam pembelajaran ilmu medis di McMaster University Canada, model pembelajaran ini menghadapkan siswa pada suatu masalah dunia nyata sehingga siswa dapat mengembangkan kemampuan berpikir tingkat tinggi dan keterampilan penyelesaian masalah serta memperoleh pengetahuan baru terkait dengan permasalahan tersebut.

Langkah-langkah model PBL terdiri dari 5 tahap proses,yaitu :

1. Proses orientasi siswa pada masalah.

Pada tahap ini guru menjelaskan tujuan pembelajaran, menjelaskan logistik yang diperlukan, memotivasi siswa untuk terlibat dalam aktivitas pemecahan masalah, dan mengajukan masalah.

2. Mengorganisasi siswa.

Pada tahap ini guru membagi siswa ke dalam kelompok, membantu siswa mendefinisikan dan mengorganisasikan 
tugas belajar yang berhubungan dengan masalah.

3. Membimbing penyelidikan individu maupun kelompok.

Pada tahap ini guru mendorong siswa untuk mengumpulkan informasi yang dibutuhkan, melaksanakan eksperimen dan penyelidikan untuk mendapatkan penjelasan dan pemecahan masalah.

4. Mengembangkan dan menyajikan hasil.

Pada tahap ini guru membantu siswa dalam merencanakan dan menyiapkan laporan, dokumentasi, atau model, dan membantu mereka berbagi tugas dengan sesama temannya.

5. Menganalisis dan mengevaluasi proses dan hasil pemecahan masalah.

Pada tahap ini guru membantu siswa untuk melakukan refleksi atau evaluasi terhadap proses dan hasil penyelidikan yang mereka lakukan.

Kaitannya dengan model pembelajaran Problem Based Learning pada saat pembelajaran, pendekatan RME ini dapat diterapkan pada saat guru membimbing tahap penyelidikan siswa saat mengerjakan LK, proses pada tahap ini siswa dituntut untuk bisa membangun pengetahuannya melalui imajinasinya dalam kehidupan sehari-hari, juga mampu mengaplikasikannya pada bentuk matematisasi nya, sehingga tahap pembelajaran PBL akan terlaksana dengan adanya proses keterkaitan RME didalamnya.
Dalam penerapan RME terdapat dua jenis matematisasi yaitu matematisasi horizontal dan matematisasi vertikal. Matematisasi horizontal berkaitan dengan proses generalisasi yang diawali dengan pengidentifikasian konsep matematika berdasarkan keteraturan dan hubungan yang ditemukan melalui visualisasi dan skematisasi masalah.

Dilihat dari ciri pendekatan open-ended yang menekankan strategi penyelesaian masalah lebih dari satu, hal ini dapat mendukung terlaksananya proses pembelajaran menggunakan model PBL seperti yang dikemukakan oleh Franz (Nikmah,I 2015) yaitu "Problems are at least initially open-ended to connect previous learned knowledge with content area goals". Franz menjelaskan bahwa masalah dalam PBL setidaknya berasal dari masalah open-ended untuk menghubungkan pengetahuan yang telah dipelajari sebelumnya dengan tujuan yang ingin dicapai.

Melalui penerapan PBL dengan pendekatan open-ended ini diharapkan siswa memiliki kreativitas dalam menggunakan berbagai strategi pemecahan masalah dan dapat memahami konsep-konsep matematika sehingga hasil belajar dan tanggung jawab siswa dapat meningkat.

\section{Metode}

Metode penelitian yang penulis gunakan dalam penelitian ini adalah metode quasi eksperimen atau eksperimen semu. Dimana subjek tidak 
dipilih secara random atau acak. Dalam hal

ini penulis memberikan perlakuan terhadap dua kelas dengan model yang sama namun pendekatan yang berbeda, kelas Eksperimen I menggunakan model pembelajaran PBL menggunakan pendekatan RME sedangkan kelas Eksperimen II menggunakan model pembelajaran PBL menggunakan pendekatan Open-Ended.

Adapun kedua kelas tersebut terlebih dahulu diberikan tes awal(pre-test),yang bertujuan untuk mengetahui kemampuan awal dari masing-masing kelas, setelah melaksanakan beberapa kali proses pembelajaran dengan model pembelajaran yang berbeda, kemudian kedua kelas tersebut diberikan tes akhir(post-test).

\section{Hasil dan Pembahasan}

Dari hasil penelitian yang ditelah dilaksanakan diperoleh hasil tes awal (pretest) dan tes akhir (posttest) dari kelas yang mendapat model pembelajaran Problem Based Learning dengan pendekatan Realistic Mathematics Education dan Open-Ended juga diperoleh data hasil angket. Untuk selanjutnya diuraikan mengenai analisis data tersebut:

Tabel 1.

Data kelas Eksperimen 1

\begin{tabular}{|cccc|}
\hline Kelas & \multicolumn{3}{c}{ PBL dengan pendekatan RME } \\
\hline Tes & Pretest & Posttest & $\begin{array}{c}\text { Gain } \\
\text { Ternormalisasi }\end{array}$ \\
\hline Siswa & 37 & 37 & 37 \\
\hline Rata-rata & 3,811 & 9,189 & 0,445 \\
\hline $\begin{array}{c}\text { Standar } \\
\text { Deviasi }\end{array}$ & 2,448 & 4,332 & 0,330 \\
\hline
\end{tabular}

Tabel 2.

Data kelas Eksperimen 2

\begin{tabular}{cccc|}
\hline Kelas & \multicolumn{3}{c}{ PBL dengan pendekatan Open-Ended } \\
\hline Tes & Pretest & Posttest & $\begin{array}{c}\text { Gain } \\
\text { Ternormalisasi }\end{array}$ \\
\hline Siswa & 39 & 39 & 39 \\
\hline Rata-rata & 2,615 & 6,000 & 0,225 \\
\hline $\begin{array}{c}\text { Standar } \\
\text { Deviasi }\end{array}$ & 1,711 & 3,340 & 0,266 \\
\hline
\end{tabular}

Nilai kedua tabel dapat dilihat rata-rata tes awal dan tes akhir diperoleh bahwa nilai rata-rata kelas Eksperimen 1 dibandingkan kelas Eksperimen 2. Nilai standar deviasi tes awal dan tes akhir diperoleh bahwa nilai standar deviasi kelas Eksperimen 1 lebih tinggi dari kelas Eksperimen 2, hal tersebut menunjukan bahwa kemampuan awal kelas Eksperimen 2 lebih menyebar dan berdasarkan kualitas peningkatan dari kedua kelas yang di analisis dengan uji Gain Ternormalisasi diperoleh bahwa kualitas peningkatan dari kelas Eksperimen 1 dengan rata-rata 0,445 dan standar deviasi sebesar 0,330 memiliki interpretasi sedang, dan untuk kelas Eksperimen 2 yang memiliki rata-rata 0,266 dan standar deviasi sebesar 0,266 memiliki interpretasi rendah, hal ini jelas terlihat bawah kualitas peningkatan siswa kelas Eksperimen 1 lebih baik dari kelas Eksperimen 2.

Tabel 3. Hasil Uji Normalitas Data Tes Akhir

\begin{tabular}{|cccc|}
\hline \multirow{2}{*}{ Tes Awal } & \multicolumn{2}{c}{$\mathrm{L}$} & $\mathrm{L}$ \\
\cline { 2 - 3 } & $\mathrm{L}_{\text {tabel }}$ & $\mathrm{L}_{\text {tabel }}$ & \\
\hline Eksperimen 1 & 0,148 & 0,106 & $\begin{array}{c}\text { Berdistribusi } \\
\text { normal }\end{array}$ \\
\hline Eksperimen 2 & 0,144 & 1,161 & $\begin{array}{c}\text { Tidak } \\
\text { berdistribusi } \\
\text { normal }\end{array}$
\end{tabular}


Pada tabel diatas, terlihat bahwa kelas Eksperimen 1 mempunyai nilai $L_{\text {tabel }}=$ $\mathrm{L}_{0,05}(36)^{\wedge} 0,5=0,148$ dan $L_{\text {maks }}=0,106$, maka $L_{\text {maks }}<L_{\text {tabel, }}$ sehingga data hasil tes akhir kelas Eksperimen 1 berdistribusi normal dan kelas Eksperimen 2 mempunyai nilai $L_{\text {tabel }}=$ $\mathrm{L} 0,05(38)^{\wedge} 0,5=0,144$ dan $L_{\text {maks }}=0,161$, maka $L_{\text {maks }}>L_{\text {tabel, }}$ sehingga data hasil tes akhir kelas Eksperimen 2 tidak berdistribusi normal.

Seperti pada data yang diperoleh bawah kedua sampel tidak berdistribusi normal, maka untuk langkah selanjutnya adalah dilakukan uji statistik non parametrik yaitu dengan uji Mann Whitney sebagai berikut:

Sebelum melakukan perhitungan, penulis merumuskan hipotesis nol dan hipotesis alternatifnya, yaitu:

Ho: Kemampuan komunikasi matematis siswa antara yang mendapatkan model Problem Based Learning menggunakan pendekatan Realistic Mathematic Education tidak lebih baik dari pada pendekatan Open-Ended.

Ha: Kemampuan komunikasi matematis siswa antara yang mendapatkan model Problem Based Learning menggunakan pendekatan Realistic Mathematic Education lebih baik dari pada pendekatan Open-Ended.

Diperoleh nilai $z_{\text {tabel }}=1,645$ karena nilai $Z_{\text {hitung }}=3,166$ berada pada daerah penerimaan Ha yaitu: $z_{\text {hitung }}>z_{\text {tabel }}$ dapat disimpulkan bahwa: Kemampuan komunikasi matematis antara siswa yang mendapatkan model pembelajaran PBL menggunakan pendekatan RME lebih baik dari pada pendekatan Open-Ended.

Dilihat dari uji normalitas kelas Eksperimen 1 dan 2 memang dari keduanya tidak ada perbedaan yang signifikan karena kaduanya memang belum diberikan materi pelajaran tersebut, namun jika dilihat dari nilai rata-rata hasil pretest dan standar deviasi nya terlihat kelas Eksperimen 1 lebih baik dari kelas Eksperimen 2. Dan setelah mendapatkan pelajaran dari hasil posttest, kemudian dari kualitas peningkatannya, dari lembar observasi siswa dan dilihat dari skala sikap sangat jelas bahwa kelas Eksperimen 1 lebih baik dari kelas Eksperimen 2. Dari hasil tersebut dapat disimpulkan bahwa kemampuan komunikasi matematis siswa yang menggunakan model pembelajaran PBL dengan menggunakan pendekatan RME dan Open-Ended. Tetapi meskipun dari hasil pretes, posttest, kualitas peningkatan, dan sikap siswa kelas Eksperimen 1 lebih dominan dari kelas Eksperimen 2, tetapi pada dasarnya dari kedua kelas telah terjadi peningkatan kualitas belajar.

\section{Penutup}

Penutup ditulis untuk mengarahkan pembaca mendapatkan hal-hal penting yang tidak dangkal dan sempit. Penutup terdisi dari dua bagian, kesimpulan dan saran. Kesimpulan menyajikan ringkasan dari uraian mengenai hasil dan pembahasan, mengacu pada tujuan penelitian. Berdasarkan kedua hal tersebut dikembangkan pokok-pokok pikiran baru 
yang merupakan esensi dari temuan penelitian.

Berdasarkan rumusan masalah, hasil penelitian, dan pembahasan seperti yang telah dikemukakan pada bab sebelumnya, diperoleh kesimpulan sebagai berikut:

1. Kemampuan komunikasi matematis antara siswa yang mendapatkan model pembelajaran Problem Based Learning menggunakan pendekatan Realistic Mathematic Education lebih baik dari pada pendekatan OpenEnded.

2. Kualitas peningkatan kemampuan komunikasi matematis siswa untuk kelas PBL dengan menggunakan pendekatan RME berinterpretasi sedang.

3. Kualitas peningkatan kemampuan komunikasi matematis siswa untuk kelas PBL dengan menggunakan pendekatan Open-Ended berinterpretasi rendah.

4. Interpretasi sikap siswa kelas PBL dengan menggunakan pendekatan RME berinterpretasi baik.

5. Interpretasi sikap siswa kelas PBL dengan menggunakan pendekatan Open-Ended berinterpretasi baik.

Berdasarkan hasil penelitian, peneliti mengajukan beberapa saran yang dapat membangun dalam peningkatan pembelajaran matematika yaitu:

1. Model pembelajaran PBL dengan pendekatan RME bisa dijadikan alternatif untuk menyampaikan materi tentang SPLSV pada siswa karena pada pembelajaran ini siswa diharapkan dapat mengaplikasikannya pada kehidupan sehari-hari, dan dengan model pembelajaran ini siswa dihadapkan terlebih dahulu pada kehidupan sehari-hari siswa, sehingga mereka bisa berimajinasi untuk kemungkinan menyelesaikan soal tes yang diberikan dengan mudah.

2. Penelitian dengan model pembelajaran $\mathrm{PBL}$ dengan pendekatan RME dan Open-Ended harus direncanakan dengan matang apalagi dari segi pembuatan soal karena model ini menenkankan pada berbagai soal-soal yang harus mereka selesaikan dengan cara yang berbeda.

3. Penelitian ini hanya berlaku untuk siswa kelas VII di SMP Negeri 1 Cikajang. Untuk mengetahui efektifitas pembelajaran ini dapat dilakukan penelitian dengan populasi dan jenjang yang lebih luas serta dengan materi yang berbeda.

Bagi peneliti selanjutnya diharapkan dapat meneliti keberhasilan model pembelajaran $\mathrm{PBL}$ dengan pendekatan RME dan Open-Ended ini pada materi lain.

\section{DAfTAR PUstaka}

Firdaus, dkk. (2013). Upaya Peningkatan Hasil Belajar Siswa Dengan Menggunakan Model Pembelajaran Berbasi Open-Ended. [Online] Tersedia: http://inovasimathopennded.blogspot .co.id/ [19 Mei 2016] 
Husna, dkk (2013). Peningkatan kemampuan pemecahan masalah dankomunikasi matematis siswa sekolah menengah pertama. [online] Tersedia:

http://www.jurnal.unsyiah.ac.id

Lestari dan Yudhanegara (2015). Penelitian

Pendidikan Matematika. Bandung: Retika Aditama

Nikmah, I (2015). PENERAPAN PBL DENGAN PENDEKATAN OPEN-ENDED UNTUK MENINGKATKAN HASIL BELAJAR DAN TANGGUNG JAWAB SISWA KELAS VII MATERI SEGIEMPAT. Skripsi Jurusan Pendidikan Matematika STKIP.Garut: Tidak diterbitkan.

Sundayana, R (2015). Media dan Alat Peraga Dalam Pembelajaran Matematika. Bandung: Alfabeta. Sundayana, R (2015). Statistika Penelitian Pendidikan. Garut: STKIP Garut Press.
Wijaya, A (2012). Pendidikan Matematika Realistik. Yogyakarta: Graha IImu.

\section{Riwayat Hidup PENULIS}

Ulfah Syifa Alamiah, S. Pd.

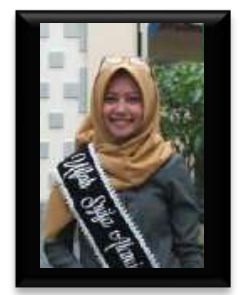

Garut, 29 September 1995. Staf pengajar di SMP. S-1 Pendidikan Matematika, STKIP Garut lulus tahun 2017; Juara 2 Porkab Kabupaten Garut Cabang Olah Raga Tarung Derajat.

\section{Ekasatya Aldila Afriansyah, S.Si., M.Sc.}

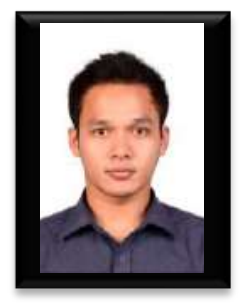

Lahir di Bandung, 4 April 1986. Dosen Tetap Yayasan STKIP Garut. Studi S1 Matematika Konsentrasi Statistika UPI, Bandung, lulus tahun 2009; S2 Pendidikan Matematika UNSRI-UTRECHT, Palembang-Utrecht, lulus tahun 2012; dan S3 Pendidikan Matematika UPI, Bandung, sampai sekarang. 
This page is intentionally left blank 